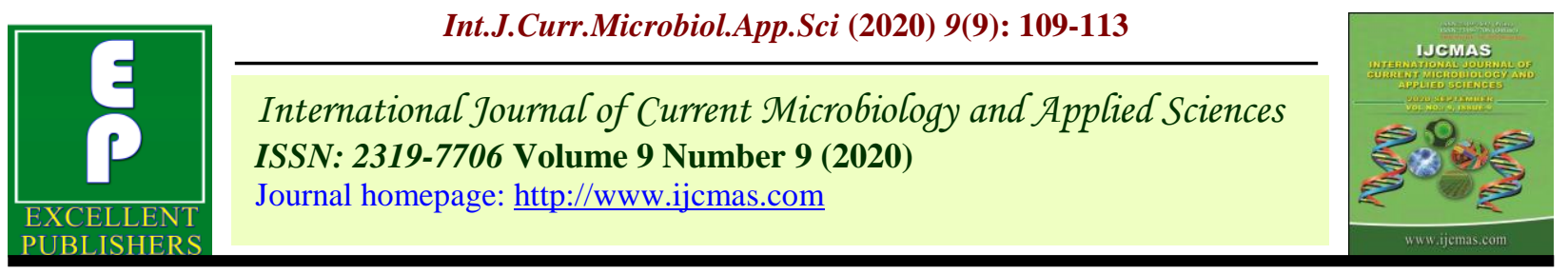

Original Research Article

https://doi.org/10.20546/ijcmas.2020.909.013

\title{
Thermal Indices and Yield Correlations of Sesame (Sesamum indicum L.) during Summer in New Alluvial Zone of West Bengal
}

\author{
Saju Adhikary*, S. Banerjee, M. Ghosh, S. K. Gunri and B. Mukherjee \\ Department of Agronomy, Faculty of Agriculture, Bidhan Chandra Krishi Viswavidyalaya, \\ Mohanpur, Nadia-741252, W.B., India \\ *Corresponding author
}

\section{A B S T R A C T}

\section{Keywords}

Phenophase,

Sesame, Sowing

date, Thermal

indices, Variety

Article Info

Accepted:

04 August 2020

Available Online:

10 September 2020
The effects of 4 sowing dates (15February, 1March, 15March and 1April) on phenology and thermal indices of 3 varieties (Tilottama, Rama and Savitri) of sesame (Sesamum indicum L.) was studied in split-plot design with 3 replications at Bidhan Chandra Krishi Viswavidyalaya, Jaguli, Nadia, West Bengal during pre-kharif (summer) season of 2017.Delay in sowing of sesame from 15 February to 1 April shortened the duration of sesame by 24.8 days (100.2 vs. 75.4 days).Mean summed growing degree days (GDD), heliothermal unit (HTU) and photothermal unit (PTU) for entire life cycle of sesame were recorded as $1584.87^{\circ} \mathrm{C}$ day, $10871.8^{\circ} \mathrm{C}$ hour and $19607.98^{\circ} \mathrm{C}$ hour, respectively. The correlation studies revealed that GDD $\left(\mathrm{r}=-0.893^{* *}\right)$ and PTU $\left(\mathrm{r}=-0.898^{* *}\right)$ during flower initiation to capsule initiation showed negative $(\mathrm{P}<0.01)$ effect on seed yield of sesame in New Alluvial Zone of West Bengal.

\section{Introduction}

Sesame (Sesamum indicum L.), one of the oldest oilseed crops, is traditionally grown in our country for thousands of years. In West Bengal, it is cultivated during kharif and prekharif season with low inputs less care and management. It occupies 1.96 lakh ha land with the production of 1.85 lakh tonnes and productivity of $942 \mathrm{~kg} \mathrm{ha}^{-1}$ in the state during
2013-14.Among different cultivation practices, sowing time is an important parameters which affect the production of sesame to a great extent. The phenological development of sesame varieties under different growth environment along with related thermal indices have not been determined and correlated with the yield of the crop in India, more preciously in the state of West Bengal. The low yield of sesame 
varieties under delayed sown conditions leads to discourage growers resulting to less total area under sesame cultivation.

Although genetic potentiality of varieties is important for improved yield and quality of sesame, but sowing time influences the growth and production to a great extent. Sharma (2005) reported 69 and 39\% variation in seed yield of sesame due to differences in temperature and variety, respectively. In the background, it becomes imperative to identify suitable sowing date and varieties of sesame during pre-kharif season in the New Alluvial Zone of West Bengal.

\section{Materials and Methods}

A field experiment was conducted at the Instructional Farm $\left(22^{\circ} 93^{\prime} \mathrm{N}\right.$ latitude, $88^{\circ} 53^{\prime}$ E longitude and $9.75 \mathrm{~m}$ altitude) of Bidhan Chandra Krishi Viswavidyalaya (BCKV), Jaguli, Nadia, West Bengal during summer (pre-kharif) season of 2017. The treatments, replicated thrice in a split-plot design consisted of 4 sowing dates (15February, 1March, 15March and 1April) in main plots and 3 sesame varieties (Tilottama, Rama and Savitri) in sub-plots. The soil was welldrained gangetic alluvial, neutral in reaction (pH 7.0), low in organic carbon $(0.57 \%)$, available $\mathrm{N}\left(330.4 \mathrm{~kg} \mathrm{ha}^{-1}\right), \mathrm{P}\left(44.5 \mathrm{~kg} \mathrm{ha}^{-1}\right)$ and $\mathrm{K}\left(238.6 \mathrm{~kg} \mathrm{ha}^{-1}\right)$. Seeds of sesame varieties were sown in furrows at $30 \mathrm{~cm}$ apart in $4 \mathrm{~m} \times 3 \mathrm{~m}$ plots and thinning was done at 18 days after sowing (DAS) to maintain optimum population. A uniform fertilizer does of $60: 40: 40 \mathrm{~kg} / \mathrm{ha}$ of $\mathrm{N}: \mathrm{P}_{2} \mathrm{O}_{5}: \mathrm{K}_{2} \mathrm{O}$ including $\mathrm{N}$ in 2 splits was applied to all the experimental units. Sesame as a pre-kharif crop was grown under norwester showers along with need-based irrigation during the cropping period.

The phenophases (viz. emergence, flower initiation, capsule initiation and maturity) of sesame varieties at different sowing dates were noted by regular field inspection method. The daily meteorological data for the period of investigation were collected from the Department of Agricultural Meteorology and Physics, BCKV, West Bengal. Growing degree days (GDD) $\left[\left(\mathrm{T}_{\max }+\mathrm{T}_{\min }\right) / 2-\mathrm{T}_{\mathrm{b}}\right]$ was calculated taking $10^{\circ} \mathrm{C}$ as base temperature (Nuttonson, 1955), heliothermal unit (GDD $\times$ Bright sunshine hour) (Singh et. al., 1990) and photothermal units [GDD $\times$ Day length] Nuttonson (1948). The correlation studies between thermal indices and seed yield were made. The data obtained in the study were analyzed using 'Analysis of Variance' technique (ANOVA) following standard statistical procedures (Gomez and Gomez, 1984).

\section{Results and Discussion}

Four phenophases of sesame crop were studied; sowing to emergence (S-E), emergence to flower initiation (E-FI), flower initiation to capsule initiation (FI-CI) and capsule initiation to maturity (CI-M) in the study. The duration of 15 February sown sesame crop was 100.2 days, which was reduced by 91.1 days (1 March), 85.3 days (15 March) and 75.4 days (1 April) for delay in sowing in the investigation (Table 1). Sondarva et al., (2014) reported the similar trend of successive decrease in duration of sesame for delay sowing from February to March at Gujarat, India. Based on life cycle, three sesame varieties could be arranged as: Tilottama (91.2 days) > Savitri (87.0days) > Rama (85.2 days).

Mean GDD from sowing to emergence (E), flower initiation (FI), capsule initiation (CI) and maturity $(\mathrm{M})$ were 76, 512, 188 and $807^{\circ} \mathrm{C}$ days, respectively (Table 2). Like phenophase duration summed GDD for entire life cycle of sesame was gradually decreased with delay in sowing from 15 
Table.1 Effect of sowing date and variety on phenology and thermal indices of sesame during pre-kharif season

\begin{tabular}{|c|c|c|c|c|c|}
\hline Treatment & $\begin{array}{l}\text { Sowing to } \\
\text { emergence } \\
(S-E)\end{array}$ & $\begin{array}{c}\text { Emergence to } \\
\text { flower initiation } \\
(\mathrm{E}-\mathrm{FI})\end{array}$ & $\begin{array}{c}\text { Flower initiation } \\
\text { to capsule } \\
\text { initiation } \\
(\mathbf{F L}-\mathbf{C I}) \\
\end{array}$ & $\begin{array}{c}\text { Capsule } \\
\text { initiation to } \\
\text { maturity } \\
(\mathbf{C L}-\mathbf{M}) \\
\end{array}$ & $\begin{array}{c}\text { Sowing to } \\
\text { maturity } \\
(\mathrm{S}-\mathrm{M})\end{array}$ \\
\hline \multicolumn{6}{|c|}{ Growing degree days $\left({ }^{\circ} \mathrm{C}\right.$ days) } \\
\hline \multicolumn{6}{|l|}{ Sowing date } \\
\hline 15 February & 81 & 505 & 238 & 886 & 1710 \\
\hline 1 March & 83 & 511 & 185 & 843 & 1621 \\
\hline 15 March & 59 & 521 & 170 & 805 & 1555 \\
\hline 1 April & 82 & 511 & 162 & 697 & 1452 \\
\hline S. $\operatorname{Em}( \pm)$ & 1.49 & 1.66 & 3.53 & 5.09 & 4.80 \\
\hline $\mathrm{CD}(\mathrm{P}=\mathbf{0 . 0 5})$ & 5.28 & 5.86 & 12.45 & 17.98 & 16.94 \\
\hline \multicolumn{6}{|l|}{ Variety } \\
\hline Tilottama & 86 & 534 & 204 & 830 & 1654 \\
\hline Rama & 69 & 495 & 179 & 789 & 1533 \\
\hline Savitri & 73 & 507 & 184 & 804 & 1568 \\
\hline S. $\operatorname{Em}( \pm)$ & 1.91 & 2.82 & 1.85 & 4.07 & 5.02 \\
\hline CD $(P=0.05)$ & 5.78 & 8.53 & 5.61 & 12.30 & 15.17 \\
\hline \multicolumn{6}{|c|}{ Heliothermal unit $\left({ }^{\circ} \mathrm{C}\right.$ days) } \\
\hline \multicolumn{6}{|l|}{ Sowing date } \\
\hline 15 February & 297 & 3412 & 1507 & 6354 & 11570 \\
\hline 1 March & 513 & 3308 & 1447 & 5924 & 11191 \\
\hline 15 March & 481 & 3691 & 670 & 6060 & 10902 \\
\hline 1 April & 641 & 2824 & 1261 & 5098 & 9824 \\
\hline S. $\operatorname{Em}( \pm)$ & 7.07 & 10.17 & 29.32 & 47.27 & 38.32 \\
\hline $\mathrm{CD}(\mathrm{P}=0.05)$ & 36.39 & 35.90 & 103.45 & 166.76 & 135.19 \\
\hline \multicolumn{6}{|l|}{ Variety } \\
\hline Tilottama & 545 & 3444 & 1334 & 6056 & 11379 \\
\hline Rama & 440 & 3222 & 1122 & 5712 & 10496 \\
\hline Savitri & 465 & 3260 & 1207 & 5808 & 10741 \\
\hline S. $\operatorname{Em}( \pm)$ & 12.03 & 18.24 & 15.17 & 33.01 & 29.24 \\
\hline $\mathrm{CD}(\mathbf{P}=\mathbf{0 . 0 5})$ & 36.39 & 55.16 & 45.87 & 99.81 & 88.41 \\
\hline \multicolumn{6}{|c|}{ Photothermal unit ( ${ }^{\circ} \mathrm{C}$ hour) } \\
\hline \multicolumn{6}{|l|}{ Sowing date } \\
\hline 15 February & 978 & 6198 & 2944 & 10992 & 21112 \\
\hline 1 March & 1017 & 6286 & 2298 & 10457 & 20059 \\
\hline 15 March & 730 & 6449 & 2082 & 10010 & 19270 \\
\hline 1 April & 1015 & 6293 & 2017 & 8665 & 17991 \\
\hline S. $\operatorname{Em}( \pm)$ & 18.33 & 20.39 & 43.82 & 63.83 & 57.43 \\
\hline $\mathrm{CD}(P=0.05)$ & 64.69 & 71.93 & 154.60 & 225.20 & 202.61 \\
\hline \multicolumn{6}{|l|}{ Variety } \\
\hline Tilottama & 1060 & 6580 & 2521 & 10314 & 20475 \\
\hline Rama & 849 & 6102 & 2209 & 9797 & 18957 \\
\hline Savitri & 897 & 6238 & 2017 & 9981 & 19392 \\
\hline S. $\operatorname{Em}( \pm)$ & 23.46 & 34.73 & 22.81 & 50.56 & 61.84 \\
\hline CD $(P=0.05)$ & 70.94 & 105.03 & 68.97 & 152.90 & 187.01 \\
\hline
\end{tabular}


Table.2 Correlations between plant characters and thermal indices at different growth stages of sesame during pre-kharif season

\begin{tabular}{|c|c|c|c|c|c|c|c|c|c|c|c|c|}
\hline \multirow[t]{2}{*}{ Parameter } & \multicolumn{4}{|c|}{$\begin{array}{c}\text { Growing degree days } \\
\left({ }^{\circ} \mathrm{C} \text { day }\right)\end{array}$} & \multicolumn{4}{|c|}{ Heliothermal units $\left({ }^{\circ} \mathrm{C}\right.$ hour$)$} & \multicolumn{4}{|c|}{ Photothermal units $\left({ }^{\circ} \mathrm{C}\right.$ hour $)$} \\
\hline & S-E & E-FI & FI-CI & CI-M & S-E & E-FI & FI-CI & CI-M & S-E & E-FI & FI-CI & CI-M \\
\hline Plant height & -.354 & .369 & $-.814^{* *}$ & $-.725^{* *}$ & $.783^{* * *}$ & -.101 & $-.610^{*}$ & -.541 & -.291 & .431 & $-.821^{* *}$ & $-.719^{* * *}$ \\
\hline $\begin{array}{l}\text { Number of capsules } \\
\text { plant }^{-1}\end{array}$ & $-.802^{* *}$ & -.078 & $-.722^{* *}$ & -.288 & .189 & .263 & $-.720^{* *}$ & -.184 & $-.786^{* *}$ & .005 & $-.739^{* *}$ & -.285 \\
\hline Test weight & $-.723^{* *}$ & -.080 & $-.807^{* *}$ & $-.693^{*}$ & .377 & -.058 & $-.810^{* *}$ & -.485 & $-.676^{*}$ & -.006 & $-.824^{* *}$ & $-.687^{*}$ \\
\hline Seed yield & -.526 & -.041 & $-.893^{* *}$ & $-.577^{*}$ & $.580^{*}$ & -.070 & $-.584^{*}$ & -.489 & -.488 & .035 & $-.898^{* *}$ & -.575 \\
\hline Stover yield $^{-1}$ & -.486 & -.115 & $-.907^{* *}$ & $-.873^{* *}$ & $.637^{*}$ & -.379 & -.575 & $-.746^{* *}$ & -.434 & -.052 & $-.909^{* *}$ & $-.871^{* *}$ \\
\hline Oil content & $-.723^{* *}$ & -.080 & $-.807^{* *}$ & $-.693^{*}$ & .377 & -.058 & $-.810^{* *}$ & -.485 & $-.676^{*}$ & -.006 & $-.824^{* *}$ & $-.687^{*}$ \\
\hline
\end{tabular}

$\mathrm{S}-\mathrm{E}=$ Sowing to emergence; E-FI = Emergence to flower initiation; FI-CI = Flower initiation to capsule initiation; CI-M = Capsule initiation to maturity Sample size: $\mathrm{n}=36$; $*$ Correlation is significant at the 0.05 level (2-tailed); ** Correlation is significant at the 0.01 level (2-tailed). 
February $\left(1710^{\circ} \mathrm{C}\right.$ day) to 1 April $\left(1452^{\circ} \mathrm{C}\right.$ day $)$ Tilottama required maximum summed GDD ( $1654{ }^{\circ} \mathrm{C}$ day) to complete the life cycle, while Rama had lowest GDD (1532 ${ }^{\circ} \mathrm{C}$ day) from sowing to maturity.

The variation in mean daily temperature and bright sunshine hour among four sowing dates resulted in varied accumulated heliothermal units at different phenophase and life cycle of sesame crop. Early sowing (15 February) of sesame recorded the highest summed total HTU $\left(11570.2^{\circ} \mathrm{C}\right.$ hour) for entire life cycle, which was gradually decreased due to delay in sowing on 1 March $\left(11191^{\circ} \mathrm{C}\right.$ hour $), 15$ March $\left(10902^{\circ} \mathrm{C}\right.$ hour) and 1 April $\left(9824.2^{\circ} \mathrm{C}\right.$ hour) in the investigation (Table 1).

Temperature generally governed the onset of different phenophases in sesame crop, but day length had also influence on photothermal requirements of the crop. Mean cultivar summed PTU at different phenophases were recorded as $935^{\circ} \mathrm{C}$ hour (sowing to emergence), $6306^{\circ} \mathrm{C}$ hour (emergence to flower initiation), $2335^{\circ} \mathrm{C}$ hour (flower initiation to capsule initiation), $10030^{\circ} \mathrm{C}$ hour (capsule initiation to maturity) and $19608^{\circ} \mathrm{C}$ hour (sowing to maturity) (Table 1).

The correlation studies showed that of the number of capsules plant ${ }^{-1}$ was negatively $(\mathrm{P}<0.01)$ influenced by GDD, HTU and PTU during flower initiation to capsule initiation (FICI).GDD ( $\left.\mathrm{r}=-0.577^{*}\right)$ during flower initiation to capsule initiation and capsule initiation to maturity $(\mathrm{CI}-\mathrm{M})$, while HTU $\left(\mathrm{r}=-0.584^{* *}\right)$ and PTU $\left(\mathrm{r}=-0.898^{* *}\right)$ during FI - CI had negative effect on economic yield of sesame in the investigation. Similar negative influence $(\mathrm{P}<0.05$ OR $\mathrm{P}<0.01)$ of GDD, HTU and PTU as oil content has noted in the study. Thus low temperature, less bright sunshine and day length during reproductive stage $(\mathrm{FI}-\mathrm{CI}$ and $\mathrm{CI}-\mathrm{M}$ ) might be desirable for better seed yield and oil content of sesame during pre-kharif season in New alluvial zone of West Bengal.

\section{References}

Gomez, K. A. and Gomez, A. A. (1984). Statistical Procedures for Agricultural Research, 2nd edn. Singapore: John Wiley \& Sons.

Nuttonson, M. Y. (1948). Some preliminary observations of phonological data as a tool in the study of photoperiod and thermal requirements of various plant materials. In: a symposium on vernalization and photoperiodism. Ed.

Nuttonson, M. Y. (1955). Wheat climatic relationships and use of phenology in ascertaining the thermal and photothermal requirement of wheat. American Institute of Crop Ecology. Washington D.C.

Sharma, P. B. (2005). Fertilizer management in sesame (Sesamum indicum L.) based intercropping system in Tawa Command area. Journal of Oilseeds Research, 22: 63-65.

Singh, G., Narwal, S. S., Rao, V. U. M. and Dahiya, D. S. (1990). Effect of sowing date on requirement of growing degree days, heliothermal units and photothermal units, and phenology of winter maize (Zea mays). Indian Journal of Agricultural Science, 60(11): 723-731.

Sondarva, K. N., Rank, H. D. and Jayswal, P. S. (2014). Summer sesame response to moisture and thermal regimes. African Journal of Agricultural Research, 9(27): 2095-2103.

\section{How to cite this article:}

Saju Adhikary, S. Banerjee, M. Ghosh, S. K. Gunri and Mukherjee, B. 2020. Thermal Indices and Yield Correlations of Sesame (Sesamum indicum L.) during Summer in New Alluvial Zone of West Bengal. Int.J.Curr.Microbiol.App.Sci. 9(09): 109-113. doi: https://doi.org/10.20546/ijcmas.2020.909.013 